УДК 347.923

DOI https://doi.org/10.32849/2663-5313/2019.9.06

\title{
Оксана Хотинсъка-Нор,
}

докт. юрид. наук, дочент,

професор кафедри правосуддя юридичного факультету

Київського начіонального університету імені Тараса Шевченка

\section{ІНСТИТУТ СУДОВИХ ПОВІСТОК У ЦИВІЛЬНОМУ СУДОЧИНСТВІ УКРАЇНИ}

Стаття присвячена дослідженню інституту судових повісток у иивільному судочинстві Україн, реалізачія якого є важливою гарантією дотримання таких принципів судового прочесу, як гласність, відкритість, диспозитивність, змагальність і рівність сторін. На підставі системного аналізу норм Цивільного процесуального кодексу України виявлено низку недоліків у регулюванні інституту судових повісток, серед яких - нечіткість і неузгодженість прочесуальних норм, що спричиняють неоднозначне їх тлумачення та ускладнюють їх реалізачію. За низкою ознак, притаманних різним видам судових повісток, охарактеризовано та надано визначення поняттям «судовий виклик» $i$ «судове повідомлення». Різне спрямування передбачених видів судових повісток зумовлює різні вимоги щодо строків їх направлення. Проаналізовано передбачені законодавством способи вручення та надсилання судових повісток, які різняться залежно від процесуального статусу учасника судового процесу та наявності необхідної для належного повідомлення інформації. Констатовано пріоритетність сповіщення учасників судового процесу засобами електронного зв'язку, зокрема направлення судових повісток на офіиійну електронну адресу. Проте такий порядок сповіщення ускладнюється у зв'язку з відсутністю законодавчого визначення поняття «офічійна електронна адреса». Виявлено неузгоженість норм процесуального законодавства з правилами, що регулюють надання послуг поштового зв'язку. Ї̈ наслідком є те, що судові повістки повертаються до суду з позначкою «за закінченням строку зберігання». Це не може вважатися належним повідомленням особи та негативно позначається на ході справи. Як аргумент наведено відповідну правову позииію Верховного Суду. За допомогою судової практики, напращьованої судом касаційної інстаниії, окреслено найбільш актуальні питання, що виникають у процесі реалізації інституту судових повісток у иивільному судочинстві. Серед них, зокрема, акцентовано увагу на необхідності врахування обсягу повноважень представника, якому направляється повістка, та строку їх дії. Насамкінеиь зроблено висновок про системний характер недоліків у законодавчому регулюванні інституту судових повісток.

Ключові слова: цивільне судочинство, судові повістки, судові повідомлення, виклик до суду, інформування учасників процесу.

Постановка проблеми. У найзагальнішому вигляді вимоги, яким має відповідати будь-яка національна процесуальна система, щоб належним чином забезпечувати реалізацію покладених на неї завдань щодо ефективного та справедливого розгляду справ, передбачені у статті 6 Конвенції про захист прав людини та основоположних свобод. Відповідно до ії змісту кожен має право на справедливий і публічний розгляд його справи упродовж розумного строку незалежним і безстороннім судом, встановленим законом, який вирішить спір щодо його прав та обов'язків цивільного характеру або встановить обгрунтованість будь-якого висунутого проти нього кримінального обвинувачення. Ця конструкція охоплює широкий спектр процесуальних принципів, засобів і гарантій, які розвиваються з огляду на динамічність практики ЄСПЛ. Серед них варто виокремити питання належного інформу- вання учасників судового процесу як необхідної умови реалізації у цивільному, та й не тільки, судочинстві засад гласності, відкритості, диспозитивності, змагальності та рівності сторін. Із цією метою законодавством передбачено інститут судових повісток, що $€$ комплексним міжгалузевим інститутом, який відіграє важливу роль у цивільному, господарському, кримінальному та адміністративному судочинстві. Проте у вітчизняній науці цивільного процесуального права йому приділено найменше уваги.

Аналіз останніх досліджень. Більшість наукового доробку, який так чи інакше висвітлює питання, пов'язані з викликами та повідомленнями учасників цивільного судочинства, розглядає інститут судових повісток у контексті їх процесуальних наслідків. Так, наприклад, у літературі справедливо звертається увага на залежність від його ефективного функціонування дотри- 
мання розумних строків розгляду справи Своєю чергою С.А. Дергачев характеризує сповіщення учасників справи як правостворюючий юридичний факт, тобто як «умову, що дає змогу суду здійснювати ті чи інші процесуальні дії» [1]. А Т.Т. Алієв і М.Г. Цуцкова називають належне сповіщення необхідною умовою та однією 3 передумов виконання завдань і досягнення цілей цивільного судочинства [2, с. 4].

У будь-якому разі інститут судових повісток у цивільному судочинстві відзначається яскравим прикладним характером. Недоліки його правового регулювання, серед яких нечіткість і неузгодженість процесуальних норм, невдалі законодавчі формулювання та конструкції тощо, призводять до негативних наслідків для всіх без винятку учасників судового процесу.

Постановка завдання. У раховуючи множинність і різноманітність питань, пов'язаних із реалізацією законодавчих норм, що регулюють засади, засоби та способи інформування учасників судового процесу, в межах цієї публікації ми зупинимося лише на тих, які становлять особливий інтерес з огляду на ï практичну значимість. Отже, ми маємо на меті з'ясувати теоретичні деструкції у сфері регулювання інституту судових повісток у цивільному судочинстві та висвітлити практичні проблеми реалізації відповідних процесуальних норм у контексті актуальної практики Верховного Суду.

Виклад основного матеріалу. У Цивільному процесуальному кодексі України (ЦПК України) правила сповіщення (інформування) учасників судового процесу акумульовано у ст.ст. 128-132, охоплених гл. 7 розділу І. 3 першого ж погляду та ознайомлення зі змістом ст. 128 ЦПК України, яка передбачає «ази» досліджуваного інституту, очевидною стає допущена помилка законодавчої техніки структурно-реквізитного характеру. Мова про те, що главу 7 , як структурно ємкісну одиницю нормативноправового акта, що охоплює декілька статей, названо «Судові виклики і повідомлення», поняття яких є видовим стосовно родового поняття «Судові повістки», використаного у назві ст. 128 ЦПК України. Саме 3 положень останньої випливає, що інститут судових повісток передбачає два їх різновиди: 1) судові повістки про виклик; 2) судові повістки-повідомлення. У будь-якому разі йдеться про встановлені процесуальним законом засоби інформування суб'єктів цивільного судочинства 3 різним ступенем їх імперативності, характером трансльованої інформації та процесуальним статусом адресата. В останньому випадку знову звертає на себе увагу наявність нормативного недоліку. Так, ч. 1 ст. 128 ЦПК України передбачає, що суд викликає учасників справи у судове засідання або для участі у вчиненні процесуальної дії, якщо визнає їх явку обов'язковою. Частина 2 ст. 128 ЦПК України встановлює, що суд повідомляє учасників справи про дату, час і місце судового засідання чи вчинення відповідної процесуальної дії, якщо їх явка $€$ необов'язковою. Таким чином, ідеться лише про учасників справи, склад яких визначено у ст. 42 ЦПК України, та серед обов’язків яких закріплено: з'являтися в судове засідання за викликом суду, якщо їх явка визнана судом обов'язковою; виконувати процесуальні дії у встановлені законом або судом строки (ст. 43 ЦПК України). Водночас приписи ч. 9 ст. 128 ЦПК України спрямовані до таких учасників судового процесу, як свідок, експерт, перекладач і спеціаліст. Аналіз зазначених положень у системному зв'язку 3 назвою ст. 128 ЦПК України та змістом інших його норм дає змогу стверджувати, що суб'єктний склад інституту судових повісток охоплює не лише учасників справи, а загалом учасників судового процесу, за винятком секретаря судового засідання, судового розпорядника та помічника судді.

Диференціація судових повісток за низкою згаданих вище ознак дає можливість зазначити таке.

1) Виклик учасників справи шляхом направлення судової повістки про виклик здійснюється судом у разі, якщо їх явка у судове засідання або для участі у вчиненні процесуальної дії є обов'язковою (безпосередньо етимологія слова «виклик» передбачає імперативний припис, вимогу до особи). Так, наприклад, суд може визнати обов'язковою участь у судовому засіданні сторони, яка подала заяву про розгляд справи за їі відсутності, для надання особистих пояснень (п. 5 ч. 2 ст. 223 ЦПК України).

Ігнорування вимоги суду щодо явки зумовлює для особи відповідні наслідки. Зокрема, за загальним правилом, встановленим ст. 223 ЦПК України, неявка у судове засідання будь-якого учасника справи за умови, що його належним чином повідомлено про дату, час і місце цього засідання, не перешкоджає розгляду справи по суті. У разі неявки у судове засідання без поважних причин або без повідомлення причин належним чином поінформованого відповідача, який не подав відзив, та за наявності згоди позивача суд може ухвалити у справі заочне рішення (ст. 280 ЦПК України). Крім того, у разі невиконання учасником справи його обов'язків, зокрема ухилення від вчинення дій, покладених на нього судом, суд 
може застосовати до такого учасника справи заходи процесуального примусу - штраф (ст. 148 ЦПК У країни).

Отже, судовий виклик є владною, обов'язковою до виконання вимогою суду до учасників судового процесу, від явки та дій яких залежить рух цивільної справи, що забезпечується передбаченими законом заходами примусу та мірою відповідальності відповідних суб'єктів.

2) Повідомлення учасників справи шляхом направлення судової повістки-повідомлення здійснюється судом у разі, якщо їх явка у судове засідання чи для вчинення процесуальної дії є необов'язковою. У такому разі йдеться про забезпечення права учасників справи бути поінформованим про дату, час і місце судового засідання та реалізацію права на особисту участь у судовому засіданні на власний розсуд.

М.Г. Цуцкова слушно зазначає, що у повідомленні містяться відомості, що вказують на можливість реалізації особою, яка бере участь у справі, комплексу належних їй прав, пов'язаних із залученістю у цивільне судочинство. Отримання особою судової повістки-повідомлення є передумовою приведення в дію потенційно наявного обсягу правомочностей суб'єкта цивільних процесуальних правовідносин (повідомлення про право) [3, с. 9].

Отже, судове повідомлення можна визначити як доведення до відома учасників судового процесу значимої процесуальної інформації, що створює підстави для реалізації на їх власний розсуд потенційно наявного у них комплексу процесуальних прав.

Різне спрямування передбачених видів судових повісток зумовлює різні вимоги щодо строків їх направлення. Так, для судових повісток про виклик встановлено обмежувальний строк, пов’язаний із датою судового засідання, який має бути достатнім для явки особи в суд і підготовки до участі в судовому розгляді справи. Особа, яка викликається, має отримати судову повістку про виклик не пізніше як за п’ять днів до дня судового засідання.

Судова повістка-повідомлення має бути направлена особі «завчасно», що означає раніше від призначеної дати, часу [4, с. 63]. Тобто дата отримання особою відповідної інформації має темпорально передувати даті проведення судового засідання чи вчинення процесуальної дії.

Ураховуючи наведене, строк направлення судових повісток визначається судом окремо в кожному конкретному випадку з урахуванням специфіки справи, обраного способу сповіщення та характеру дії, яку необхідно вчинити особі.
Найбільш проблематичною на практиці є реалізація процесуальних норм, що регулюють правила (способи, порядок, наслідки) надсилання та вручення судових повісток. Зауважимо, що вони передбачені двома різними статтями (ст. 128 і ст. 130) ЦПК України, положення яких перекликаються та подекуди дублюють один одного. Це також, на нашу думку, слід визнати недоліком, що ускладнює процес правозастосування.

Отже, ст. 128 ЦПК України передбачено способи вручення та надсилання судових повісток, які різняться залежно від процесуального статусу учасника судового процесу та наявності необхідної для належного повідомлення інформації.

1) Так, учасникам справи судові повістки можуть бути вручені безпосередньо в суді або надіслані одним із таких способів: а) на офіційну електронну адресу у разі їі наявності; б) разом із розпискою рекомендованим листом 3 повідомленням про вручення у разі, якщо електронна адреса відсутня; в) через кур'єрів за адресою, зазначеною учасником справ; г) у справах про видачу обмежувального припису - телефонограмою, телеграмою, засобами факсимільного зв'язку, електронною поштою або повідомленням через інші засоби зв'язку (зокрема, мобільного), які забезпечують фіксацію повідомлення або виклику; г) через засоби мобільного зв'язку шляхом надсилання текстових повідомлень із зазначенням веб-адреси відповідної ухвали в ЄДРСР за наявності відповідної письмової заяви учасника справи, який не має офіційної електронної адреси, та технічної можливості.

«Довідка про доставку SMS, згідно з якою позивачам було доставлено $S M S$-повідомлення про судове засідання не може вважатися доказом належного повідомлення про дату, час $і$ місие судового засідання, оскільки згідно з пунктом 2 Порядку надсилання учасникам судового процесу (кримінального провадження) текстів судових повісток у вигляді SMS-повідомлень, затвердженого наказом Державної судової адміністрачії України від 01 червня 2013 року № 73, текст судової повістки може бути надісланий судом Учаснику SMS-повідомленням лише після подання ним до суду заявки про намір отримання судової повістки в електронному виглядi за допомогою SMS-повідомлення. Така заявка оформляється безпосередньо в суді або шляхом роздруковування та заповнення Учасником форми, яка розміщена на офіиійному вебпорталі судової влади Украӥни» (постанова Касаиійного иивільного суду у складі Верховного Суду від 27 березня 2019 р. у справі № 201/6092/17) [5]. 
2) Свідок, експерт, спеціаліст, перекладач викликаються чи повідомляються судом: а) шляхом вручення їм судової повістки стороною чи ії представником, які були видані їм судом за їх згодою; б) телефонограмою, телеграмою, засобами факсимільного зв'язку, електронною поштою або повідомленням через інші засоби зв'язку (зокрема, мобільного), які забезпечують фіксацію повідомлення або виклику.

У разі відкладення розгляду справи особи, незалежно від їх процесуального статусу, про дату, час і місце наступного судового засідання можуть бути повідомлені під розписку.

Якщо стосовно таких учасників, як відповідач, третя особа, свідок, немає відомостей про зареєстроване місце проживання (перебування), місцезнаходження чи місце роботи вони, а також заінтересована особа у справах про видачу обмежувального припису викликаються до суду через оголошення на офіційному вебсайті судової влади України. Оголошення про виклик розміщається не пізніше ніж за десять днів, а у разі розгляду справи про видачу обмежувального припису - не пізніше 24 годин до дати відповідного судового засідання. Особа вважається повідомленою про дату, час і місце розгляду справи 3 дня опублікування оголошення.

«Не може вважатися доказом належного повідомлення про дату, час $i$ місие судового засідання оголошення, розмішене на сайті Судова влада України, оскільки такий порядок повідомлення розрахований на відповідача, третю особу, свідка, заінтер есованих осіб, а не на позивача» (постанова Касачійного иивільного суду у складі Верховного Суду від 27 березня 2019 р. у справі № 201/6092/17) [5]

Системний аналіз положень ст. 128 і ст. 130 ЦПК України свідчить про пріоритетність сповіщення учасників судового процесу засобами електронного зв'язку, зокрема направлення судових повісток на офіційну електронну адресу. Водночас законодавче визначення поняття «офіційна електронна адреса» наразі відсутнє. За наявними на момент цієї публікації законодавчими ініціативами під нею пропонується розуміти адресу електронної пошти юридичної особи та фізичної особи-підприємця, що використовується для офіційного листування в електронному вигляді та є незмінною до внесення запису про державну реєстрацію припинення юридичної особи, припинення підприємницької діяльності фізичної особи [6]. Крім того, за правилами, передбаченими ст. 14 ЦПК України, статус «офіційної електронної адреси» в цивільному судочинстві

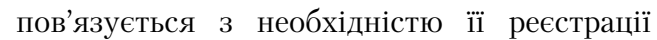
в Єдиній судовій інформаційно-телекомунікаційній системі, функціонування якої в судах є певною перспективою. Отже, до дня початку її функціонування, відповідно до підп. 15.1 п. 15 ч. 1 розд. ХІІІ «Перехідні положення» ЦПК України, надсилання документів здійснюється у паперовій формі.

Таким чином, судові повістки за відсутності в адресата офіційної електронної адреси вручаються фізичним особам або службовій особі юридичної особи під розписку.

Розписка про одержання судової повістки є формою фіксації факту її одержання особою, якій вона адресована, з обов'язковим зазначенням відповідної дати та власним підписом особи. Дата, проставлена в розписці, вважається днем вручення судової повістки. Розписка про одержання судової повістки приєднується до матеріалів справи та є доказом належного повідомлення особи про дату, час і місце судового засідання чи вчинення відповідної процесуальної дії.

За загальним правилом судова повістка вручається адресату особисто. Якщо його не виявлено (тимчасово відсутній) в місці проживання, повістка під розписку може бути вручена будь-кому з повнолітніх членів сім'ї, які проживають разом 3 особою. Декларується, що в такому разі адресат судової повістки є належно повідомлений про час, дату і місце судового засідання, вчинення іншої процесуальної дії. На практиці ж реалізація такої норми є утрудненою з огляду на відсутність у ЦПК України визначення кола осіб, які належать до членів сім'ї особи-адресата для цілей кодексу.

У разі відсутності за адресою особи (будь-кого з повнолітніх членів сім’ї) особа, яка доставляє судову повістку, має негайно повернути іï до суду з поміткою про причини невручення. «Негайно» у цьому разі слід розуміти як найкоротший термін протягом робочого дня, в який має бути здійснена відповідна дія, з моменту виникнення підстави для її вчинення.

Особою, яка доставляє судову повістку та повертає до суду відповідну розписку, є: 1) кур'єр - у разі надсилання судової повістки через нього; 2) працівник поштового зв'язку - у разі надсилання судової повістки рекомендованим листом 3 повідомленням про вручення.

Дії працівників поштового зв'язку та правила надання такого роду послуг регулюються Законом України «Про поштовий зв'язок» і Правилами надання послуг поштового зв'язку, затвердженими постановою Кабінету Міністрів України від 05 березня 2009 р. № 270 (далі - Правила). 
Відповідно до п. 17 Правил рекомендовані листи 3 позначкою «Судова повістка» приймаються для пересилання лише з рекомендованим повідомленням про їх вручення. Вручення поштового відправлення (рекомендованого листа) згідно з п. 2 Правил $є$ виробничою операцією, яка полягає у видачі поштового відправлення

Таким чином, 3 урахуванням вимог ст. 130 ЦПК України вручення поштового відправлення 3 позначкою «Судова повістка», як виробнича операція, має здійснюватися лише особисто адресату або будькому з повнолітніх членів його сім'ї лише за адресою доставки. Адже тільки так можливо встановити наявність або відсутність за конкретною адресою особи-адресата.

Водночас Правила встановлюють можливість видачі рекомендованих листів 3 позначкою «Судова повістка», адресованих фізичним особам, у приміщенні об'єкта поштового зв'язку. Крім того, передбачається, що у разі відсутності адресата або повнолітніх членів його сім'ї повідомлення про надходження зазначеного реєстрованого поштового відправлення вкладається до абонентської поштової скриньки адресата (п. 99 Правил). Відповідно до пп. 116, 117 Правил, якщо вручити поштове відправлення неможливо, воно зберігається об'єктом поштового зв'язку місця призначення протягом одного місяця 3 дня надходження та після закінчення строку зберігання повертається відправнику. У разі невручення рекомендованого листа 3 позначкою «Судова повістка» 3 поважних причин рекомендований лист разом з бланком повідомлення про вручення повертається за зворотною адресою не пізніше ніж через п'ять календарних днів 3 дня надходження листа до об'єкта поштового зв'язку місця призначення із зазначенням причини невручення.

Неузгодженість наведених Правил із процесуальними нормами призводить до того, що судові повістки повертаються до суду з позначкою оператора «за закінченням строку зберігання». Це не може вважатися належним повідомленням особи про дату, час і місце судового засідання чи вчинення відповідної процесуальної дії, оскільки не свідчить про відмову позивача від одержання повістки чи про його незнаходження за адресою, повідомленою суду.

«... положення иивільного прочесуального законодавства не передбачають повернення рекомендованих листів з відміткою «за закінченням встановленого строку зберігання», така відмітка не передбачена як причина невручення судового повідомлення. Ця відмітка не розкриває суті причини неможли- вості вручити адресату відповідний рекомендований лист. Отже, подібна відмітка не дає суду обтрунтованих процесуальних підстае для визначення факту належного повідомлення сторони у судовій справі, зокрема не визначає, чи адресат відмовився від отри мання судового повідомлення, чи адресат відсутній, чи особа, якій адресовано судову повістку, не виявлена в місиі проживання.

..Ані Закон про поштовий зв'язок, ані Правила не передбачають для судових повідомлень, направлених рекомендованим листом, довідки із зазначенням причини повернення - «за закінченням встановленого строку зберігання», яка засвідчується підписом працівника поштового зв'язку та відбитком календарного штемпеля. Зазначене за своїм сутнісним змістом не $\epsilon$ причиною невручення, a $\epsilon$ причиною повернення. Із зазначених норм права випливає, що у разі повернення рекомендованого листа з позначкою «Судова повістка» мають зазначатись причини невручення, а не причини повернення такого рекомендованого листа» (окрема ухвала Касачійного иивільного суду у складі Верховного Суду від 23 січня 2019 р. у справі 761/15565/16-u) [7].

Відповідно до ч. 5 ст. 130 ЦПК України судова повістка вважається врученою учаснику справи, якщо вона вручена його представнику. Важливим у цьому аспекті $€$ врахування: 1) обсягу повноважень, якими наділяється представник, і 2) строку їх дії.

1) «... телефонограма щодо повідомлення секретарем судового засідання про розгляд справи судом апелячійної інстаниї̈ К-вої О.C. (яка представляла інтереси позивача в судi периої інстаниії) <..> не може слугувати підтвердженням повідомлення позивача про розгляд справи судом апеляиійної інстаниіі, оскільки <..> не враховує встановлені договором про надання правової допомоги обмеження на представниитво адвокатом К-вою О.С. лише у Вінницькому міському суді» (постанова Касаиійного иивільного суду у складі Верховного Суду від 20 червня 2018 р. у справі № 127/2871/16-u) [8].

2) «..відкладаючи 24 березня 2016 року розгляд справи через неявку позивача та ї представника на 21 квітня 2016 року, апелячійний суд знову надіслав судові повістки на адресу ОСОБА 9, яка вже не була представником позивача, а саму ОСОБА 1 за вказаною нею адресою про судове засідання не повідомив. У рекомендованих повідомленнях про вручення поштового відправлення міститься відмітка про отримання судових повісток уповноваженим ОСОБА_10, однак

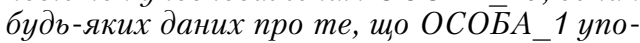
вноважувала вказану особу на отримання 
адресованої їй кореспондениї, причому не за місием ї проживання, матеріали справи не містять. Отже, позивач не була належним чином повідомлена про розгляд справи в судовому засіданні...» (постанова Касаиійного иивільного суду у складі Верховного Суду від 15 березня 2018 року у справі № 456/71/10) [9].

\section{Висновки}

Наведені у межах цієї публікації авторські думки та правові позиції Верховного Суду не вичерпують усієї проблематики, пов'язаної 3 реалізацією інституту судових повісток у цивільному судочинстві. Проте й їх досить, щоб констатувати наявність системних недоліків у чинному законодавстві, які зумовлюють увагу Європейського суду з прав людини в контексті неналежного забезпечення особі права на справедливий суд.

\section{Список використаних джерел:}

1. Дергачев С.А. Юридический и фактический адрес юридического лица: проблемы надлежащего извещения. Вестник Высшего Арбитражного Суда Российской Федеращии. 2008. № 3 (184). C. 16-27.

2. Алиев Т.Т., Цуцкова М.Г. Информационное обеспечение в гражданском и арбитраж- ном процессе : монография. Москва : Институт мировых цивилизаций, 2018. 168 с.

3. Цуцкова М.Г. Информационное обеспечение в гражданском судопроизводстве автореф. ...канд. юрид. наук. Саратов, 2015. 28 с

4. Словник української мови: в 11 томах. Том 3, 1972. $744 \mathrm{c}$

5. Постанова Касаційного цивільного суду у складі Верховного Суду від 27 березня 2019 р. у справі № 201/6092/17. URL: http:// reyestr.court.gov.ua/Review/80783087.

6. Проєкт Закону про внесення змін до Закону України «Про державну реєстрацію юридичних осіб, фізичних осіб-підприємців та громадських формувань» щодо присвоєння офіційної електронної адреси під час державної реєстрації від 26 грудня 2017 р. № 7443. URL: http://w1.c1.rada.gov.ua/pls/zweb2/ webproc4_1?id=\&pf3511 $=63226$.

7. Окрема ухвала Касаційного цивільного суду у складі Верховного Суду від 23 січня 2019 р. у справі 761/15565/16-ц. URL: http:// reyestr.court.gov.ua/Review/79805802.

8. Постанова Касаційного цивільного суду у складі Верховного Суду від 20 червня 2018 р. у справі № 127/2871/16-ц. URL: http:// reyestr.court.gov.ua/Review/74895462.

9. Постанова Касаційного цивільного суду у складі Верховного Суду від 15 березня 2018 року у справі № 456/71/10. URL: http:// reyestr.court.gov.ua/Review/72819370.

The article researches the institute of subpoenas in the civil judiciary of Ukraine, the implementation of which is an important guarantee of observance of such principles of litigation as publicity, openness, dispositiveness, competitiveness and equality of parties. Based on a systematic analysis of the rules of the Civil Procedure Code of Ukraine, have been identified a number of shortcomings in the regulation of the institute of subpoenas, among them are the unclear and inconsistent of procedural rules, which cause ambiguous interpretation and complicate their implementation. By a number of features inherent in different types of subpoenas, have been characterized and defined the terms of "subpoena" and "court notice". Different directions of the provided types of subpoenas give rise to different requirements regarding the terms of sending. Analyzed methods of delivery and sending of subpoenas, provided by law, which differ depending on the procedural status of the trial participant and the availability of the information required for proper communication. Priority was given to the notification of trial participants by electronic communications, in particular sending subpoenas to an official e-mail address, which is complicated at the same time by the lack of a legislative definition of the term "official e-mail address". Identified the inconsistency of procedural legislation and the rules governing the provision of postal services. Its consequence is that the subpoenas returns to the court marked as "expired storage period". This can't be considered as a proper notification of person and negatively affects the case. As an argument given appropriate legal position of the Supreme Court. Using the case law of the court of cassation author has outlined the most pressing issues that arise during realization of the institute of subpoenas in civil proceedings. Among them, the emphasis was placed on the need to take into account the scope of authority of the agent to whom the summons is being sent and the period of their validity. Finally, a conclusion is drawn about the systemic nature of the deficiencies in the legislative regulation of the institute of judicial summons.

Key words: civil proceedings, subpoenas, subpoena, court notices, summons, informing process participants. 